\title{
MANIFESTASI KLINIS DAN DIAGNOSIS MIGREN VESTIBULAR
}

\author{
CLINICAL MANIFESTATION AND DIAGNOSIS OF VESTIBULAR MIGRAINE
}

Freddy Sitorus, * Ni Nengah Rida Ariarini, * Dyah Tunjungsari*

\begin{abstract}
Vestibular migraine (VM) is the most common cause of recurrent spontaneous vertigo on outpatient dizziness clinics. Clinical manifestation of VM is highly variable. Patient may present symptoms like vertigo, dizziness, tinnitus, visual disturbance, phonophobia, photophobia, aural fullness, paresthesia, nausea, and vomiting. Most VM patients have normal physical examination between attacks. Diagnostic criteria of this disease based on joint consensus of the International Headache Society (IHS) together the Barany Society published in 2012. The Differential diagnosis of this disease are benign paroxysmal positional vertigo (BPPV), Meniere's disease, and acute ischemic attack. Moreover, vestibular migraine treatment is almost the same as for migraine.
\end{abstract}

Keywords: Clinical manifestation, diagnosis, vestibular migraine

\section{ABSTRAK}

Migren vestibular (MV) merupakan penyebab tersering vertigo spontan berulang pada pasien di poliklinik spesialis yang menangani rasa goyang. Manifestasi klinis dari migren vestibular sangat bervariasi. Pasien dapat mengeluhkan gejala seperti vertigo, pusing, tinitus, gangguan penglihatan, fonofobia, fotofobia, aural fullness, parestesi, mual, dan muntah. Pemeriksaan fisik pada pasien MV biasanya normal di antara serangan. Penegakan diagnosis penyakit ini berdasarkan konsensus bersama antara International Headache Society (IHS) dan Barany Society pada tahun 2012. Diagnosis diferensial penyakit ini adalah benign paroxysmal positional vertigo (BPPV), penyakit Meniere, dan serangan iskemik akut. Sampai saat ini, terapi untuk migren vestibular hampir sama dengan terapi migren pada umumnya.

Kata kunci: Diagnosis, manifestasi klinis, migren vestibular

*Departemen Neurologi FK Universitas Indonesia/RSUPN Dr. Ciptomangunkusumo, Jakarta. Korespondensi: freddysitor@yahoo. com.

\section{PENDAHULUAN}

Migren dan vertigo merupakan keluhan yang sering ditemukan dalam praktik sehari-hari ${ }^{1}$ dengan prevalensi masing-masing $13-16 \%$ dan $36,2 \%{ }^{2}$ Hubungan antara kedua keluhan ini sudah ditemukan sejak abad ke-19, ${ }^{3}$ namun baru tiga dekade terakhir dilaporkan asosiasi keduanya yang disebut sebagai migren vestibular (MV). Entitas penyakit ini pertama kali dideskripsikan oleh Dieterich dan Brandt pada 1999 yang sebelumnya disebut migrainous vertigo, vestibular-associated migraine, migraine associated vestibulopathy, dan vertigo associated vertigo. Berdasarkan klasifikasi International Classification of Headache Disorders (ICHD) tahun 2014, semua penyakit ini disebut migren vestibular. ${ }^{1,3}$

Migren vestibular dapat memengaruhi hingga $1 \%$ dari populasi umum. ${ }^{2}$ Penyakit ini merupakan penyebab tersering vertigo spontan berulang pada pasien-pasien di poliklinik spesialis yang menangani kasus gangguan vestibular ${ }^{2}$ dan dapat terjadi pada usia berapa pun, terutama perempuan dengan rasio 1,5-5:1 dibandingkan laki-laki. ${ }^{1,3}$

\section{PEMBAHASAN}

\section{Patofisiologi}

Mekanisme migren vestibular belum dapat dijelaskan. Beberapa peneliti menghubungkan teori cortical spreading depression (CSD) dan keterlibatan sistem trigeminovaskular dengan terjadinya vestibular migren. Gelombang CSD dapat mencapai korteks vestibular atau bahkan nuklei sistem vestibular, sehingga menyebabkan gejala vestibular. Namun, durasi episode MV bervariasi dari hitungan detik hingga hitungan hari, tidak sesuai dengan karakteristik aura pada migren. ${ }^{4}$

Telinga bagian dalam menerima persarafan dari cabang oftalmika ganglion trigeminal melalui arteri basilaris dan arteri karotis internal anterior. Rangsangan kimiawi dan elektrik pada ganglion trigeminal menyebabkan peningkatan aliran darah telinga bagian dalam secara signifikan dan perubahan permeabilitas vaskular dengan ekstravasasi protein plasma ke telinga dalam. Hal ini diperkirakan menyebabkan hipersensitivitas koklea/vestibular hingga menimbulkan gejala vestibular. ${ }^{4}$ 


\section{Manifestasi Klinis}

Pasien MV dapat mengalami gejala seperti vertigo, pusing, tinitus, gangguan penglihatan, fonofobia, fotofobia, aural fullness, parestesi, mual, dan muntah. ${ }^{1,6-10}$ Tipe vertigo yang paling sering dialami adalah vertigo internal $(73 \%)$ atau sensasi semu diri sendiri berputar, diikuti pusing spontan $(47,2 \%)$, dan vertigo eksternal (25\%) atau sensasi semu lingkungan sekitar berputar. ${ }^{9}$ Durasi vertigo bervariasi dari menit ke hari, paling sering 1-60 menit (44,8\%). ${ }^{9}$ Kebanyakan pasien juga mengalami gejala terkait vertigo, seperti fonofobia, tinitus, mual, dan muntah. ${ }^{9}$ Vertigo dapat mendahului serangan migren atau terjadi selama serangan migren. ${ }^{6}$ Sekitar $25 \%$ pasien mengalami nyeri kepala yang disertai vertigo dan $30 \%$ pasien mempunyai vertigo yang tidak terkait dengan nyeri kepala. ${ }^{4}$ Sekitar setengah pasien MV juga dapat mengalami kelainan psikiatrik, kebanyakan berupa gangguan cemas dan depresi. ${ }^{6,11-12}$

Kebanyakan pasien MV mempunyai pemeriksaan fisik dan hasil laboratorium normal di antara serangan. ${ }^{1,6-10}$ Neugebauer dkk melaporkan subtle saccadic pursuit pada hampir dua pertiga pasien MV di antara serangan. ${ }^{10,13}$ Nistagmus posisional adalah temuan terbanyak $(60 \%),{ }^{8}$ terutama nistagmus posisional persisten. ${ }^{10,14}$ Selama serangan, dapat muncul nistagmus konsisten dengan abnormalitas vestibular perifer, abnormalitas vestibular sentral, atau gabungan dari sentral atau perifer. ${ }^{10,15}$ Hazzaa $\mathrm{N}$ dkk melaporkan 37\% pasien MV tidak menunjukkan abnormalitas videonistagmografi (VNG).

\section{Diagnosis}

Pada tahun 2012, International Headache Society (IHS) bersama dengan Barany Society mengeluarkan konsensus kriteria diagnostik migren vestibular, yaitu: ${ }^{3}$
A. Setidaknya terdapat lima episode yang memenuhi kriteria $\mathrm{C}$ dan $\mathrm{D}$.
B. Terdapat migren atau riwayat migren dengan atau tanpa aura menurut ICHD.
C. Terdapat gejala vestibular dengan intensitas sedang atau berat yang berlangsung lima menit hingga 72 jam.

D. Terdapat setidaknya setengah episode gejala yang diikuti oleh setidaknya satu dari tiga gejala berikut:

1. Sakit kepala dengan setidaknya dua dari empat karakteristik berikut: unilateral, berdenyut, intensitas nyeri sedang atau berat, atau dipengaruhi oleh aktivitas fisik ringan.

2. Fotofobia dan fonofobia.

3. Aura visual.

E. Tidak dapat dijelaskan dengan diagnosis vestibular atau ICHD lain.

Ada pula yang dikatakan sebagai probable migren vestibular, yaitu: ${ }^{3}$ A) setidaknya terdapat lima episode dengan gejala-gejala vestibular sedang atau berat yang berlangsung selama 5 menit atau 72 jam, B) hanya satu kriteria $\mathrm{B}$ atau $\mathrm{C}$ migren vestibular terpenuhi (riwayat migren atau gambaran migren selama episode serangan), dan C) tidak dapat dijelaskan oleh diagnosis vestibular atau ICHD lain.

Kriteria diagnosis untuk migren tanpa aura menurut ICHD edisi ketiga adalah: ${ }^{16}$

Setidaknya terdapat lima serangan yang memenuhi kriteria B-D.

1. Nyeri kepala yang berlangsung 4-72 jam (ketika tidak tertangani atau tidak tertangani dengan tuntas).

2. Nyeri kepala yang setidaknya memenuhi dua dari empat karakteristik: lokasi unilateral, kualitas berdenyut, intensitas nyeri sedang atau berat, dipicu oleh atau menyebabkan menghindari aktivitas fisik rutin (berjalan atau naik tangga).

3. Selama nyeri kepala setidaknya terdapat gejala: mual dan/atau muntah serta fotofobia dan fonofobia.

4. Tidak dapat dijelaskan dengan diagnosis ICHD-3 lainnya.

\section{Diagnosis Diferensial}

Gejala MV dapat berupa vertigo posisional murni sehingga mirip dengan benign paroxysmal positional vertigo (BPPV). ${ }^{16}$ Pada MV fase akut, 
nistagmus yang terjadi adalah nistagmus posisional. ${ }^{3}$ Episode vertigo cenderung lebih singkat pada MV (menit ke hari) dengan frekuensi yang lebih sering (beberapa hari dalam setahun) daripada BPPV yang episode serangannya berlangsung selama berminggu-minggu hingga berbulan-bulan jika tidak tertangani. ${ }^{3,16}$

Gejala MV juga dapat berupa ketulian, tinitus, dan telinga terasa penuh, sehingga mirip dengan pasien penyakit Meniere. ${ }^{3,16}$ Apalagi ketulian pada MV bisa separah pada penyakit Meniere. Hampir $30 \%$ pasien dengan sindrom Meniere juga mengalami MV. ${ }^{16}$ Secara umum, penyakit Meniere dibedakan dengan MV berdasarkan gejala kepenuhan telinga atau nyeri sebelum serangan dan terdapat tinitus dan/ atau tuli selama episode. ${ }^{16}$

Pada usia lanjut dapat dipertimbangkan serangan iskemik akut, terutama jika terdapat faktor risiko vaskular, gejala yang mendadak, riwayat serangan total kurang dari satu tahun, dan terdapat bukti angiografik atau Doppler transkranial adanya patologi vaskular di arteri basilar proksimal atau vertebralis. ${ }^{3}$ Episode vertigo pada serangan iskemik akut biasanya berlangsung beberapa menit serta sering berkaitan dengan mual dan muntah. ${ }^{16}$

\section{Tata Laksana}

Hingga saat ini, pilihan tata laksana medikamentosa pada MV belum memiliki bukti ilmiah yang kuat. ${ }^{18-20}$ Ulasan Cochrane pada 2015 tidak dapat menemukan uji klinis terandomisasi yang well designed yang dapat menyimpulkan terapi MV optimal. ${ }^{19}$ Klinisi biasanya bergantung pada rekomendasi tata laksana migren tradisional. ${ }^{19}$

Secara umum, terdapat terapi farmakologis dan nonfarmakologis untuk migren vestibular. Tata laksana farmakologis migren berupa terapi abortif (untuk fase akut) dan terapi preventif (profilaksis) yang pemilihannya bergantung pada frekuensi serangan vestibular. ${ }^{19}$

Tata laksana abortif terbagi menjadi terapi nonspesifik, yaitu golongan obat antiinflamasi nonsteroid (OAINS), dan terapi spesifik berupa golongan ergot dan triptan. Obat-obat golongan triptan adalah obat yang biasa digunakan untuk mengatasi migren vestibular fase akut. ${ }^{18-20}$ Neuhauser dkk pada uji randomized, double-blind, placebocontrolled, crossover-after-one-attack menunjukkan subjek yang meminum Zolmitriptan $5 \mathrm{mg}$ dengan serangan migren vestibular mengalami pengurangan gejala sebesar $38 \%{ }^{19-20,25}$ Uji label-terbuka retrospektif multicenter yang lain menunjukkan 55\% pasien melaporkan resolusi komplit gejala vertigo dan $28 \%$ mengalami setengah pengurangan vertigo setelah mengonsumsi satu dosis Almotriptan $12,5 \mathrm{mg}$ secara oral dalam waktu satu jam onset vertigo. ${ }^{20,26}$

Ada beberapa jenis obat yang dapat digunakan sebagai tata laksana preventif, yaitu jika serangan kurang dapat dikontrol dengan terapi abortif atau serangan terjadi $>2$ kali per minggu. ${ }^{28}$ Taghdiri dkk dalam studi kohort label-terbuka retrospektif menunjukkan Cinnnazirine, obat penghambat kanal kalsium selektif, dengan dosis awal 37,5mg malam untuk tiga hari ditingkatkan menjadi $75 \mathrm{mg}$ untuk tiga bulan dapat mengurangi frekuensi serangan migren (dari 3,9 ke 0,75), durasi nyeri kepala (dari 24 ke 3 jam), dan intensitas nyeri kepala (dari median VAS 8 ke 1). Efek samping obat ini yang paling sering adalah penambahan berat badan $(12,5 \%)$, diikuti oleh penglihatan buram dan sedasi..$^{20,26}$

Pada sebuah studi kohort label-terbuka prospektif, Topiramat $25-50 \mathrm{mg}$ dua kali sehari selama 6 bulan mengurangi serangan vertigo bulanan (dari 5,5 ke 1), rerata serangan nyeri kepala bulanan (dari 4 ke 1), skor keparahan vertigo sampai $75 \%$, dan keparahan nyeri kepala 50\%. ${ }^{20,27}$ Efek samping terutama parestesi, kelelahan, dan tingkat konsentrasi. $^{20,29}$

Obat-obat lain yang dapat digunakan untuk tata laksana profilaksis migren vestibular adalah amitriptilin, lamotrigin, golongan penghambat beta (metoprolol atau propranolol), venlafaksin, dan asam valproat. Namun, belum ada randomized controlled study penggunaan obat-obat ini pada MV. ${ }^{18-20}$

\section{Tata Laksana Nonfarmakologis}

Terdapat tigajenis tata laksana nonfarmakologis yang dapat digunakan; ${ }^{19}$ terapi fisik vestibular, teknik self care, dan modifikasi diet. Studi retrospektif yang dilakukan oleh Baier, dkk menunjukkan bahwa terapi 
fisik vestibular mengurangi intensitas dan frekuensi episode vestibular sebanyak $46 \%$ dan mengurangi durasi serangan vertigo pada $42 \%$ pasien. ${ }^{21}$ Pada teknik self care, pasien disarankan untuk menghindari pencetus migren, mengurangi stresor, tidur lebih teratur, latihan aerobik, dan rujuk ke psikiater dalam mengatasi stresor. ${ }^{21-22}$ Coklat, kafein, dan alkohol adalah makanan potensial untuk mencetuskan migren. ${ }^{23}$ Modifikasi diet dengan mengeliminasi makanan tersebut dapat mengurangi gejala vestibular pada $14 \%$ pasien. ${ }^{24}$

\section{KESIMPULAN}

Migren vestibular sudah diakui secara definitif sebagai diagnosis sesuai ICHD-3, 2014. Penyakit ini merupakan penyebab tersering vertigo spontan berulang dengan gejala yang sangat bervariasi tidak hanya rasa berputar, tetapi juga rasa goyang yang dicetuskan oleh masalah visual, perubahan posisi kepala, dan lain-lain. Terapi MV hampir sama dengan terapi migren pada umumnya, yaitu terapi abortif dan preventif. Mendeteksi gejala vestibular migren secara dini akan memperbaiki tata laksana pada pasien dengan vertigo berulang.

\section{DAFTAR PUSTAKA}

1. Morganti LO, Salmito MC, Duarte JA, Sumi KC, Simoes JC, dkk. Vestibular migraine: clinical and epidemiological aspects. Brazilian J Otorhinolaryngol. 2016;82(4):397-402.

2. Von-Brevern M, Neuhauser H. Epidemiological evidence for a link between vertigo and migraine. J Vestib Res [serial online]. 2011 [diundung April 2018];21(6):299-304. Tersedia dari: NCBI.

3. Lempert $\mathrm{T}$, Olesen $\mathrm{J}$, Furman $\mathrm{J}$, Waterston $\mathrm{J}$, Seemungal B, Carey J, dkk. Vestibular migraine: diagnostic criteria. J Vestib Res. 2012;22(4):167-72.

4. Espinosa-Sachez JM, Lopez-Escamez JA. New insights into pathophysiology of vestibular migraine. Frontiers in Neurol. 2015;6:3.

5. Van-Ombergen A, Van-Rompaey V, Van-De-Heyning $\mathrm{P}$, Wuyts F. Vestibular migraine in an otolaryngology clinic: prevalence, associated symptoms, and prophylactic medication effectiveness. Otol Neurotol. 2015;36(1):133-8.

6. Ferster AP, Priesol AJ, Isildak H. The clinical manifestations of vestibular migraine: a review. Auris Nasus Larynx. 2017;44(3):249-52.

7. Power L, Shute W, McOwan B, Murray K, Szmulewicz D. Clinical characteristics and treatment choice in vestibular migraine. $\mathrm{J}$ Clin Neurosci. 2018;52:50-3.

8. Hazzaa N, El-Mowafy SS. Clinical features of vestibular migraine in Egypt. Egyptian J Ear, Nose, Throat Allied Sci. 2016;17(1):17-21.

9. Teggi R, Colombo B, Albera R, Asprella-Libonati G, Balzanelli C, Batuecas-Caletrio A, dkk. Clinical features, familial history, and migraine precursors in patients with definite vestibular migraine: the VMphenotypes projects. Headache: J Head Face Pain. 2018;58(4):534-44.

10. Furman JM, Balaban CD. Vestibular migraine. Ann New York Academy Sci. 2015;1343(1):90-6.

11. Best C, Tschan R, Eckhardt-Henn A, Dieterich M. Who is at risk for ongoing dizziness and psychological strain after a vestibular disorder? Neuroscience. 2009;164:1579-87.

12. Katsarava Z, Buse DC, Manack AN, Lipton RB. Defining the differences between episodic migraine and chronic migraine. Curr Pain Headache Rep. 2012;16(1):86-92.

13. Neugebauer H, Adrion C, Glaser M, Strupp M. Long-term changes of central ocular motor signs in patients with vestibular migraine. Eur.Neurol. 2013;69(2):102-7.

14. Cass SP, Ankerstjerne JK, Yetiser S, Furman JM, Balaban C, Aydogan B. Migraine-related vestibulopathy. Ann Otol Rhinol Laryngol. 1997;106(3):182-9.

15. Von-Brevern M, Zeise D, Neuhauser H, Clarke AH, Lempert T. Acute migrainous vertigo: clinical and oculographic findings. Brain. 2004;128(2):365-74.

16. Olesen J, Bes A, Kunkel R, Lance JW, Nappi G, Pfaffenrath V. The international classification of headache disorders. Edisi ke-3. Cephalalgia. 2018;38(1):1-211.

17. Salmito MC, Duarte JA, Morganti LO, Brandao PV, Nakao BH, Villa TR, dkk. Prophylactic treatment of vestibular migraine. Braz J Otorhinolaryngol. 2017;83(4):404-10.

18. Barbosa F, Villa TR. Vestibular migraine: diagnosis challenges and need for targeted treatment. Arquivos de Neuro-Psiquiatria. 2016;74(5):416-22.

19. Krauter R. Vestibular migraine diagnostic criteria and treatment options. Physician Assist Clin. 2018;3(2):3163-80.

20. Lauritsen CG, Marmura MJ. Current treatment options: vestibular migraine. Current Treat Options Neurol. 2017;19(11):38.

21. Baier B, Winkenwerder E, Dieterich M. Vestibular migraine: effects of prophylactic therapy with various drugs. A retrospective study. J Neurol. 2009;256(3):436-42. 
22. Maione A. Migraine-related vertigo: diagnostic criteria and prophylactic treatment. Laryngoscope. 2006;116(10):1782-6.

23. Slavin M, Ailani J. A clinical approach to addressing diet with migraine patients. Curr Neurol Neurosci Rep. 2017;17(2):17.

24. Johnson GD. Medical management of migrainerelated dizziness and vertigo. Laryngoscope 1998;108(2):1-28.

25. Neuhauser H, Radtke A, Von-Brevern M, Lempert T. Zolmitriptan for treatment of migrainous vertigo: a pilot randomized placebo-controlled trial. Neurol. 2003;60(5):882-3.

26. Cassano D, Pizza V, Busillo V. P074. Almotriptan in the acute treatment of vestibular migraine: a retrospective study. J Headache Pain. 2015;16(Suppl 1):A114.
27. Celebisoy N, Gokcay F, Karahan C, Bilgen C, Kirazlı $\mathrm{T}$, Karapolat H, dkk. Acetazolamide in vestibular migraine prophylaxis: a retrospective study. Eur Arch Otorhinolaryngol. 2016;273(10):2947-51.

28. Taghdiri F, Togha M, Jahromi SR, Refaeian F. Cinnarizine for the prophylaxis of migraine associated vertigo: a retrospective study. Spring. 2014;3(1):231.

29. Gode S, Celebisoy N, Kirazli T, Akyuz A, Bilgen C, Karapolat H, dkk. Clinical assessment of topiramate therapy in patients with migrainous vertigo. Headache. 2010;50(1):77-84.

30. Bisdorff AR. Management of vestibular migraine. Therapeutic advances in neurological disorders. 2011 2011;4(3):183-91. 